\begin{tabular}{|c|c|}
\hline Title & The effects of the PDCA cycle and OJT on workplace learning \\
\hline Author(s) & Matsuo, Makoto; Nakahara, Jun \\
\hline Citation & $\begin{array}{l}\text { The International Journal of Human Resource Management, 24(1), 195-207 } \\
\text { https://doi.org/10.1080/09585192.2012.674961 }\end{array}$ \\
\hline Issue Date & 2013 \\
\hline Doc URL & http:/hdl.handle.net/2115/56496 \\
\hline Rights & $\begin{array}{l}\text { This is an A uthor's A ccepted Manuscript of an article published in include the complete citation information for the } \\
\text { final version of the article as published in The International Journal of Human Resource Management } 2013 \text { copyright } \\
\text { Taylor \& Francis, av ail lable online at: } \mathrm{h} \text { ttp://www.tandfonline.com/doi /abs/10.1080/09585192.2012.674961 }\end{array}$ \\
\hline Type & article (author version) \\
\hline File Information & Matsuo \& Nakahara (2013) self-archiving.pdf \\
\hline
\end{tabular}

Instructions for use 
The International Journal of Human Resource Management,

Vol. 24, No. 1, January 2013, 195-207

\title{
The effects of the PDCA cycle and OJT on workplace learning
}

\author{
Makoto Matsuo ${ }^{a}$ and Jun Nakahara ${ }^{b}$ \\ ${ }^{a}$ Graduate School of Business Administration, Kobe University, Kobe, Japan; \\ ${ }^{\mathrm{b}}$ Center for Research and Development of Higher Education, The University of Tokyo, \\ Tokyo, Japan
}

In the present article, we examined the effects of the plan-do-check-act (PDCA) cycle and on-the-job-training (OJT) on workplace learning. We defined workplace learning based on the concept of an organizational learning cycle. Using survey data from a Japanese fire and marine insurance company, we found that PDCA, OJT (empowerment), and reflective communication had positive effects on workplace learning. These results suggest that quality management, empowerment and reflective practice may help to significantly improve workplace learning. We also discuss theoretical and managerial implications of this study.

Keywords: empowerment; OJT; organizational learning; PDCA; reflective communication; workplace learning

\section{Introduction}

The workplace has been increasingly recognized as an effective means for employee development in the fields of human resources management (HRM) and human resources development (HRD) (Raper, Ashton, Felstead and Storey 1997; Boud and Garrick 1999; van der Sluis, Williams and Hoeksema 2002; Hodkinson 2005; Clarke 2006). Garavan, Morley, Gunnigle and McGuire (2002) noted a paradigm shift involving a switch from formal, intermittent and discontinuous learning to increasingly informal, experiential, asynchronous and real-time-oriented learning. Kitching (2007) also found that workplace learning-by-doing and learning-by-interacting were routinely considered more important than externally provided training, particularly certified training, even after the initial period of employment. In a review of organizational learning literature, Easterby-Smith, Crossan and Nicolini (2000) argued that there were new opportunities for research related to the scrutiny of workplace activities and 
practices.

Despite this attention, several vital questions remain unanswered. First, no consensus on the concept of workplace learning has emerged (Clarke 2005; Fenwick 2008). To further research workplace learning, it is necessary to develop measures of workplace learning with an appropriate conceptual background. Second, several authors have underscored the role of the plan-do-check-act (PDCA) cycle and on-the-job-training (OJT) in facilitating learning (Slotte, Tynjala and Hytonen 2004; Choo, Linderman and Schroeder 2007a), although few studies have, in fact, investigated empirically the impact of these approaches on workplace learning.

Clarke (2005) distinguished between the workplace learning environment and the workplace learning outcome, where the former refers to practices and behaviors that facilitate the latter. We investigated the role of OJT and PDCA practices as learning environment factors in promoting workplace learning using learning outcome survey data from a Japanese firm.

The remainder of this article is structured as follows. We begin with an overview of workplace learning and organizational learning cycles to define the former in terms of the latter. Then, we present our hypotheses, which were based on literature on OJT and the PDCA cycle. The research methodology is then outlined and the principal findings are reviewed. Finally, we discuss the results and our conclusions.

\section{Theoretical background}

\section{Workplace learning}

The workplace offers learning opportunities, which can be defined as specific tasks and functions that provide developmental opportunities (Davies and Easterby-Smith 1984; Morrison and Brantner 1992; van der Sluis et al. 2002). According to Garavan et al. (2002), workplace learning represents a set of processes that occur within specific organizational contexts and involve acquiring and assimilating integrated clusters of knowledge, skills, values and feelings that result in fundamental changes in the foci and behaviors of individuals and teams (p. 61).

Although no consensus on the workplace learning concept has emerged, this domain clearly includes both formal learning (e.g., training and structured learning activities) and non-formal learning (learning through day-to-day work activities) that occur, in part or entirely, in the workplace (Institute of Personnel and Development 2000; Beattie 2006).

Following the work of Watkins and Marsick (1992) and Rowden (2002) classified workplace learning into three different forms: formal, informal and incidental learning. Formal learning consists of discrete, planned events or experiences used to instruct people on the performance of specifically defined jobs. Informal learning occurs through unstructured activities or spontaneous demonstrations, regardless of the existence of any expressed goal. 
Incidental learning occurs as an unintended byproduct of other activities, such as trial-and error experimentation or interpersonal interaction. Rowden (2002) reported a positive relationship between the three types of workplace learning and job satisfaction.

Previous research has suggested that the majority of workplace learning occurs through informal means (Marsick and Watkins 1990; Sorohan 1993; Rainbird and Munro 2003; Conlon 2004), and that informal learning and practice play considerable roles in developing professional expertise in the workplace (Fox 1997; Conlon 2004). The idea of 'learning by participation' has become a dominant approach to understanding workplace learning (Fuller and Unwin 2005).

Although informal learning has been emphasized in past studies, research on workplace learning has lacked a consensually accepted definition of this notion (Clarke 2005). Fenwick (2008) explained that definitions of workplace learning have varied because learning includes phenomena ranging from individual information acquisition to cultural transformation or even political emancipation.

Thus, we have defined workplace learning based on the concept of organizational learning. According to previous research, the common organizational learning process involves: (1) the acquisition of new knowledge by individuals or groups; (2) the sharing and interpretation of such knowledge within a group or an organization; (3) the incorporation of portions of this knowledge into organizational routines; and (4) the elimination of anachronistic routines (Huber 1991; Nevis, DiBella and Gould 1995; Crossan, Lane and White 1999; Yukl 2009). A similar definition was adopted by Garvin (1993), Gupta and Govindarajan (2000) and McDonnell, Gunnigle and Lavelle (2010).

Reviewing the literature on workplace learning in the fields of HRD, adult education and organization/management, Fenwick (2008) found that research in all fields examined similar problems: how to understand individual-collective learning processes, knowledge generation, knowledge sharing and factors that inhibit and facilitate these processes.

Edmondson (2002) argued that group-level analyses of organizational learning are important to connect individual-level factors, such as cognition and behavior, to organization-level outcomes because organizational learning is often measured in terms of changes at the level of the team.

Group learning has been viewed as a process for effecting changes in interactions as members acquire, share and combine knowledge, test assumptions, openly discuss differences, form new routines and adjust strategies in response to errors (Edmondson 1999; Edmondson, Bohmer and Pisano 2001).

Given that workplace learning can be examined at the micro- or sub-level of organizations, we defined this notion as the process in which new knowledge is acquired, shared, 
institutionalized and discarded, formally, informally and incidentally in the workplace. It is assumed that these processes lead to adequate solutions to workplace problems, improvement in the quality of work, accomplishment of objectives and enhancement of the abilities of junior and mid-level managers.

\section{Role of OJT and the PDCA cycle}

We investigated the roles of OJT and PDCA practices in the promotion of workplace learning. Both OJT and PDCA practices involve formal and informal routines, which can be conceptually distinguished from workplace learning as learning outcomes. Some empirical studies have suggested the importance of OJT and quality management in promoting workplace learning.

For example, Raper et al. (1997) reported that many firms in the UK have accorded more responsibility to line managers and have used OJT and quality standards to facilitate work-based learning. Slotte et al. (2004) also found that human resource professionals emphasized on-the-job learning to facilitate individual learning in the workplace. These studies suggest that practices involved in OJT and quality management play important roles in promoting workplace learning. However, few studies have examined the effects of OJT and quality management on workplace learning. Thus, we investigated the roles of OJT and the PDCA cycle in facilitating learning in the workplace.

\section{OJT practices}

OJT includes providing employees with spontaneous explanations or demonstrations related to their job responsibilities and enabling them to subsequently hone their skills by trial-and-error learning or by observing and imitating the behaviors of others (Jacobs and Osman-Gani 1999, p. 17). Although relatively little research has been reported on OJT (van der Klink and Streumer 2002), several empirical studies have examined the effectiveness of this approach. Benson (2006) analyzed survey data obtained from a large high-technology manufacturing company and reported that the OJT (number of days spent in formal OJT during the previous 12 months) was positively associated with the organizational commitment of employees and negatively correlated with intention to leave. Using datasets from two large-scale surveys, Barron, Berger and Black (1999) reported that OJT (total hours of on-site training provided during the first 3 months on a job) was positively correlated with growth in the productivity of firms. van der Klink and Streumer (2002) focused on the OJT programs of two organizations and found that managerial support during OJT had a positive impact on the progress of trainees. The

Unlike the studies mentioned above that operationalized OJT in terms of days or hours spent on tasks related to OJT, Sakakibara (2004) focused on practices in the workplace and developed a scale for OJT consisting of two dimensions: 'direct supervision from senior members' (e.g., 
'providing advice or instructions about tasks') and 'empowerment' (e.g., 'entrusting trainees with challenging tasks or making them participate in the decision making process'). On the basis of survey data obtained from a local government organization, Sakakibara found that empowerment was positively correlated with the skill development of trainees. Similarly, other previous research has indicated that empowerment stimulates learning-related activities (Cohen and Ledford 1994; Kirkman and Shapiro 1997).

The results of empirical studies have suggested that OJT practices have the potential to promote workplace learning. Of the two dimensions proposed by Sakakibara (2004), empowerment may encourage workers to acquire new knowledge or skills, and direct supervision from seniors may facilitate the sharing of knowledge or skills within the workplace. Thus, we propose the following hypotheses:

Hypothesis 1: OJT practices (direct supervision) are positively correlated with workplace learning.

Hypothesis 2: OJT practices (empowerment) are positively correlated with workplace learning.

\section{PDCA practices}

According to Hackman and Wageman (1995), total quality management (TQM) practices create positive learning environments by providing workers with a rich and diverse set of learning tools and repeatedly encouraging them to reexamine their work processes. We focused on the PDCA cycle within the context of TQM practices because the latter is a well-established framework for improving processes and facilitating continuous learning, creativity and quality management (Deming 2000; Jones, Parast and Adams 2010).

The PDCA cycle was proposed by Shewhart (1931, 1939), and is commonly used as a problem-solving model in the context of quality management (Deming 2000; Choo, Linderman and Schroeder 2007b). According to this framework, quality improvement will be effective if improvements start with a good plan $(\mathrm{P})$, activities necessary to achieve the plan are implemented (i.e., done, D), results are checked (C) to understand the causes of the results, and actions (A) are taken to improve the processes (Dahlgaard and Kanji 1995).

We focused on the PDCA cycle because it is similar to step-wise models of problem solving (Choo et al. 2007a). A commonly used problem-solving process model consists of: (1) problem definition; (2) problem analysis; (3) generation and selection of solutions; (4) testing and evaluation of solutions; and (5) development of new routines (MacDuffie 1997). Specifically, a problem is identified and analyzed during the planning phase, solutions are implemented during the doing phase and evaluated in the checking phase, and new routines are developed in the acting phase. 
O'Connor (2004) proposed a workplace learning cycle consisting of design, implementation, evaluation and assessment. Although this cycle is quite similar to the PDCA cycle, the PDCA model has been applied not only in quality but also in security (Tang 2008) and project (Srivannaboon 2009) management efforts.

On the basis of the discussion above, we predicted that PDCA practices would promote workplace learning by facilitating problem solving, and that workplaces using PDCA practices would facilitate the acquisition, sharing and institutionalization of useful, new knowledge and skills and the elimination of outdated knowledge and skills. Thus, we proposed the following hypothesis.

Hypothesis 3: PDCA practices are positively correlated with workplace learning.

\section{Reflective communication}

Previous studies on team learning have emphasized the role of reflective communication in promoting learning and performance. Edmondson (1999) conceptualized team learning behavior as an ongoing process of reflection and action, characterized by asking questions, seeking feedback and discussing errors. She reported that learning behavior was a significant predictor of teamperformance. Gibson and Vermeulen (2003) also argued that team members need to transfer and combine insights through reflective communication to reach a common understanding of what the experience or information means. Similarly, van der Vegt and Bunderson (2005) viewed team-learning behavior as an aspect of a group's interaction process, which includes asking questions, challenging assumptions and seeking different perspectives. They assumed that these activities encouraged team members to seek to acquire, share and combine task-relevant knowledge.

Reflection is necessary for learning in the team and workplace because it allows workers to critique assumptions that are taken for granted, and encourages them to be receptive to alternative ways of reasoning and behaving (Cunliffe 2002; Gray 2007).

Reflective communication is closely related to the concept of reflective practice, proposed by Schön (1983). This concept was applied initially in the fields of nursing and teacher education and is increasingly being used across professions (Moon 2004). Raelin (2002) defined reflective practice as the practice of periodically stepping back to consider the meaning of what recently transpired to others and to oneself in the immediate environment. The role of reflective practice has been emphasized in the research of learning in professional organizations (e.g., Edmondson et al. 2001). Reflective communication can be viewed as a communication style in which members are encouraged to engage in reflective practices in the workplace. Thus, we proposed the following hypothesis. 
Hypothesis 4: Reflective communication is positively correlated with workplace learning.

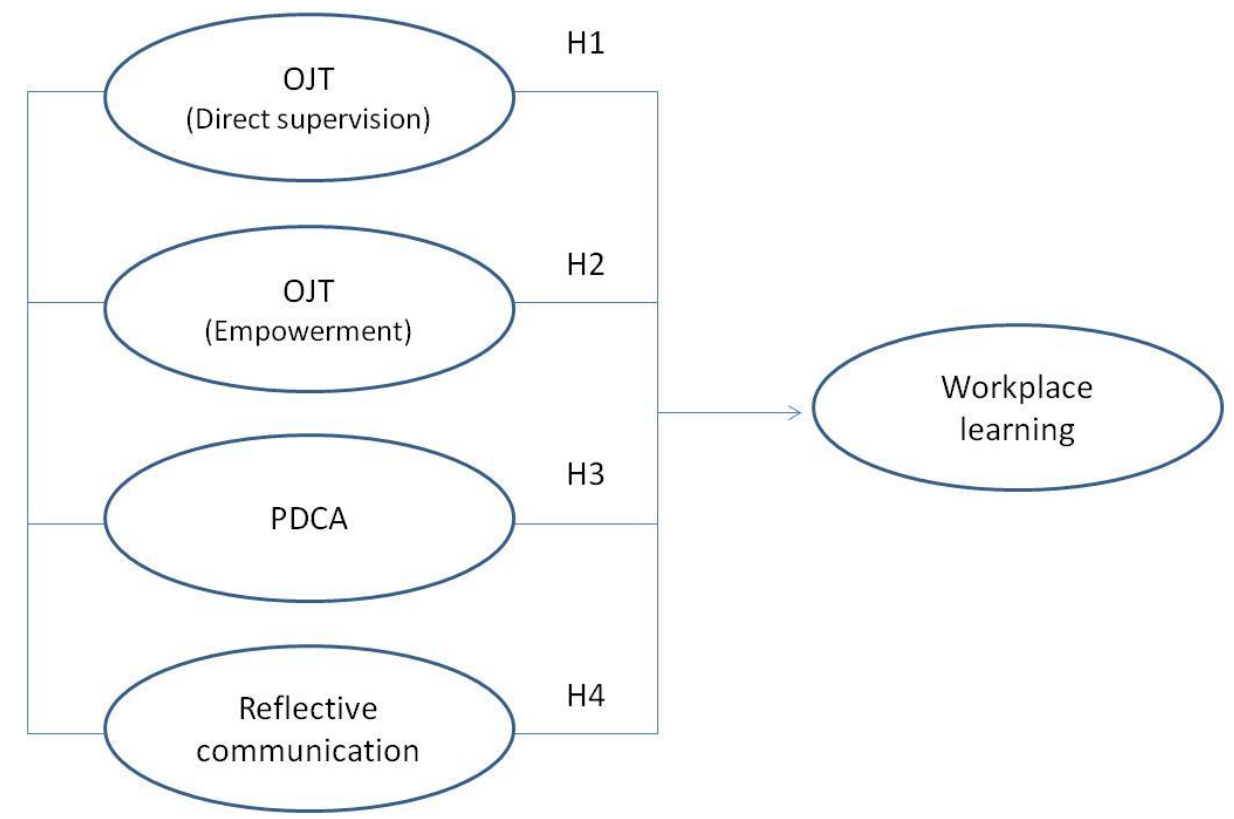

Figure 1. Research model.

\section{Research model}

Figure 1 shows the research model of this study. This model suggests that OJT practices (direct supervision, empowerment), PDCA practices and reflective communication influence workplace learning, ultimately resulting in higher performance.

We tested our hypotheses using survey data from a Japanese fire and marine insurance company. The units of analysis in this study were the work units in this company. We defined the workplace as a group of people with shared goals, responsibilities and missions who could directly interact and communicate within the organization. On the basis of this definition, work units were treated as the workplace.

\section{Methodology}

\section{Sample and data collection}

Data were collected from a Japanese fire and marine insurance company. We asked the HRD department of the firm to ask their 732 employees to complete questionnaires available on a designated website. In total, 641 responded to the questionnaires (a response rate of 87.5\%). Of the sample, $41.4 \%$ were men and $58.6 \%$ were women. These employees belonged to 124 work 
units, 64 sales units and 60 non-sales units. Because the unit of analysis was the work unit (workplace), individual data were aggregated into unit-level data (124 units). The average number of respondents per work unit was 5.05 .

\section{Measures}

Multiple-item scales were developed on the basis of items previously proposed in survey research studies. Means, standard deviations and correlations among the variables are shown in Table 1.

\section{Workplace learning}

The scale measuring workplace learning was originally developed based on the concept of organizational learning and involved four items: knowledge acquisition, knowledge sharing, knowledge institutionalization and unlearning. Each item measured workplace learning on a five-point Likert scale ( 1 . strongly disagree, 5 . strongly agree). The alpha coefficient was 0.91 . The scores for each item were used as observable variables.

\section{OJT practices}

OJT practices were measured using the scale developed by Sakakibara (2004), which consists of two dimensions: supervision (e.g., providing advice or instructions about tasks) and empowerment (e.g., entrusting trainees with challenging tasks or involving them in the decision-making process). Each item measured OJT practices on a five-point Likert scale (1. strongly disagree, 5 . strongly agree). The alpha coefficients for direct supervision (five items) and empowerment (four items) were 0.96 and 0.86, respectively. The scores for each item were used as observable variables.

\section{PDCA practices}

Because no scale for measuring the PDCA cycle has been reported, we developed a scale for this purpose based on previous work (Dahlgaard and Kanji 1995; Choo et al. 2007a) and preliminary research. During the preliminary research, we extracted items on PDCA through focus group discussions among HRM consultants with experience in developing PDCA programs for managers. PDCA practices were measured using five items. Each item measured PDCA practices on a five-point Likert scale (1. strongly disagree, 5. strongly agree). The alpha coefficient was 0.85 . The scores for each item were used as observable variables.

\section{Reflective communication}

Reflective communication was measured using six items adapted from Gibson and Vermeulen 
(2003) and van der Vegt and Bunderson (2005), which emphasize reflective communication in developing learning in the workplace. Each item measured reflective communication on a five-point Likert scale (1 . strongly disagree, 5 . strongly agree). The alpha coefficient was 0.91. The scores for each item were used as observable variables.

\section{Validation of the measures}

To evaluate the convergent validity of the model constructs, a confirmatory factor analysis with five latent constructs, namely workplace learning, PDCA, OJT (direct supervision), OJT (empowerment) and learning and learning behavior (reflective communication), with a total of 23 measures, was conducted. The results showed that all items loaded significantly on the respective constructs ( $\mathrm{p}, 0.001)$, and the goodness-of-fit statistics for the model were as follows: x 2 . 411.26, degrees of freedom (df) . 220, comparative fit index (CFI) . 0.92, Tucker-Lewis index (TLI) . 0.91 and root-mean-square error of approximation (RMSEA) . 0.08. That all the items loaded significantly on the assigned constructs and that the fit indices were relatively good provided evidence of convergent validity. The internal consistency of the constructs was evaluated by the alpha coefficient. All scales met the recommended reliability coefficient of . 0.7 (Nunnally 1978).

To estimate within-group agreement on the workplace learning scale, the $r_{w g(j)}$ (James, Demaree and Wolfe 1984) was calculated for the sample. The estimated $r_{w g(j)}$ values for workplace learning, PDCA, OJT (direct supervision), OJT (empowerment) and PDCA were $0.96,0.93,0.73,0.86$ and 0.98 , respectively. These estimates met the recommended index of > 0.7 (George 1990), reflecting a high level of agreement in the variables within work units

Because the scale of workplace learning was developed for this study, we evaluated its criterion validity (correlations between scale items and known standard measures) by correlating workplace learning with items related to sales performance using data from sales units (n . 64). Several authors have reported that organizational learning has a positive impact on organizational performance (Tippins and Sohi 2003; Lopez, Peon and Ordas 2005). Financial performance data (percentages of sales goals achieved) for the sales units and branches were obtained from the headquarters of the firm. The correlation coefficient between workplace learning and financial performance of sales units was $0.30(\mathrm{p}, 0.05)$. This result indicated that sales performance improved when useful new knowledge was acquired, shared and institutionalized and outdated knowledge was discarded. This provides evidence of the criterion validity of our measure of workplace learning. 
Table 1. Descriptive statistics and correlations.

\begin{tabular}{|c|c|c|c|c|c|c|}
\hline Variable & Mean & S.D. & 1 & 2 & 3 & 4 \\
\hline 1 Workplace learning & 3.34 & .37 & & & & \\
\hline 2 OJT (direct supervision) & 3.83 & .53 & $.40^{* *}$ & & & \\
\hline 3 OJT (empowerment) & 3.54 & .36 & $.47^{* *}$ & $.63 * *$ & & \\
\hline 4 PDCA & 3.55 & .38 & $.69^{* *}$ & $.54^{* *}$ & $.45^{* *}$ & \\
\hline 5 Reflective communication & 3.47 & .41 & $.66^{* *}$ & .62 ** & $.45^{* *}$ & $.34^{* *}$ \\
\hline
\end{tabular}

\section{Results}

Table 1 presents descriptive statistics and pair-wise correlations between variables. Structural equation modeling (SEM) was conducted to test the proposed research model because SEM allows the examination of multiple relationships simultaneously while also incorporating measurement error into the estimation process. Figure 1 presents the estimated model. Estimation of the hypothesized model resulted in x 2 . 411.26 (df . 220, p , 0.001), CFI . 0.92, TLI . 0.91 and RMSEA . 0.08. One possible explanation for the chi-squared value is this statistic's sensitivity to sample size. Other indices showed relatively adequate fits. The standardized path coefficients for the model are presented in Table 2.

OJT (direct supervision) was negatively related to workplace learning (20.31, p , 0.001), while OJT (empowerment) was positively related to workplace learning $(0.37, \mathrm{p}, 0.001)$. These results indicate that workplace learning is enhanced if the boss entrusts members with challenging tasks requiring a slightly higher ability, but learning is hindered when the boss provides members with advice and instructions about the tasks. These results do not support Hypothesis 1, but do support Hypothesis 2.

PDCA was positively related to workplace learning $(0.46, \mathrm{p}, 0.001)$, which supports Hypothesis 3 . Reflective communication was positively related to workplace learning $(0.38, \mathrm{p}$, 0.001), as predicted by Hypothesis 4. These results indicate that learning is enhanced when members engage in PDCA practices and communicate reflectively with one another in the workplace.

\section{Discussion}

We examined various hypotheses about relationships among learning practices and workplace learning using survey data. Our findings suggest that learning practices using the PDCA cycle, OJT (empowerment) and reflective communication facilitate workplace learning. 
Table 2 Structural Model Estimates.

\begin{tabular}{|c|c|c|c|c|}
\hline & & & Estimate $^{\mathrm{a}}$ & t-value \\
\hline \multicolumn{5}{|c|}{ Structural paths } \\
\hline & H1 & OJT (direct supervision) $\rightarrow$ Workplace learning & -.31 & $-3.00^{* *}$ \\
\hline & $\mathrm{H} 2$ & OJT (empowerment) $\rightarrow$ Workplace learning & .37 & $3.79^{* * * *}$ \\
\hline & $\mathrm{H} 3$ & PDCA $\rightarrow$ Workplace learning & .46 & $3.58^{* * * *}$ \\
\hline & $\mathrm{H} 4$ & Reflective communication $\rightarrow$ Workplace learning & .38 & $3.73^{* * *}$ \\
\hline \multicolumn{5}{|c|}{ Measurement model } \\
\hline \multicolumn{5}{|c|}{ OJT (direct supervision) $(\alpha=.96)^{c}$} \\
\hline & & Takes the initiative to serve as an example in the accomplishment of tasks ${ }^{b}$ & .90 & - \\
\hline & & Provide appropriate advice about tasks & .95 & $18.52^{* * * *}$ \\
\hline & & Provide the opportunities to prepare before entrusting me with the tasks & .89 & $15.47^{* * * *}$ \\
\hline & & Be acquainted with tasks & .88 & $14.87^{* * *}$ \\
\hline & & Provide precise instructions & .95 & $18.47^{* * * *}$ \\
\hline \multicolumn{5}{|c|}{ OJT (empowerment) $(\alpha=.86)^{\mathrm{c}}$} \\
\hline & & Entrust a task to me in a comprehensive way ${ }^{b}$ & .89 & - \\
\hline & & Entrust tasks to juniors from a planning stage on a regular basis & .70 & $9.17^{* * *}$ \\
\hline & & Entrust me with challenging tasks & .90 & $13.89^{* * *}$ \\
\hline & & Entrust me with tasks requiring a slightly higher ability & .64 & $8.11^{* * *}$ \\
\hline \multicolumn{5}{|c|}{$\operatorname{PDCA}(\alpha=.85)^{\mathrm{c}}$} \\
\hline & & Objectives in the workplace are quantified ${ }^{\mathrm{b}}$ & .54 & - \\
\hline & & Share specific plans among members to accomplish objectives in the workplace & .85 & $6.31^{* * *}$ \\
\hline & & The reasons for the gap between objectives and results are investigated & .88 & $6.42^{* * *}$ \\
\hline & & Sufficient time to review out experiences of tasks is offered & .84 & $6.28^{* * *}$ \\
\hline & & Lessons are extracted from work experience & .70 & $5.71^{* * *}$ \\
\hline \multicolumn{5}{|c|}{ Reflective communication $(\alpha=.91)^{\mathrm{c}}$} \\
\hline & & There is open communication in the workplace ${ }^{b}$ & .90 & - \\
\hline & & Everyone has a chance to express their opinion & .85 & $13.56^{* * *}$ \\
\hline & & Members maintain a high level of idea exchange & .88 & $14.52^{* * *}$ \\
\hline & & Members freely challenge the assumptions underlying each other's ideas and & .80 & $12.01^{* * *}$ \\
\hline & & Members engage in evaluating their weak points in attaining effectiveness & .75 & $10.59^{* * * *}$ \\
\hline \multicolumn{5}{|c|}{ Workplace learning $(\alpha=.91)^{\mathrm{c}}$} \\
\hline & & Useful new knowledge, skills, and know-how are acquired ${ }^{\mathrm{b}}$ & .72 & - \\
\hline & & Useful new knowledge, skills, and know-how are shared among members & .92 & $14.34^{* * *}$ \\
\hline & & Useful new knowledge, skills, and know-how are established as rules and procedures & .92 & $14.10^{* * *}$ \\
\hline & & Out-dated knowledge, skills, and know-how are abandoned & .85 & $9.47^{* * * *}$ \\
\hline \multicolumn{5}{|c|}{ Value represent standardized estimate. } \\
\hline $\mathrm{b}$ & \multicolumn{4}{|c|}{ The correspoinding parameter is fixed to a value of 1.00 to set the scale of measurement. } \\
\hline c & \multicolumn{2}{|c|}{ ' $\alpha$ ' represent Cronbach's alpha. } & & \\
\hline
\end{tabular}


The theoretical implications can be summarized as follows. First, PDCA practices play an important role in facilitating workplace learning, suggesting that quality management based on the PDCA cycle can significantly improve HRD. It has been suggested that the PDCA cycle facilitates problem-solving in the workplace (Choo et al. 2007a,b). Specifically, a problem is identified and analyzed in the planning phase, solutions are implemented in the doing phase, the results are evaluated and considered in the checking phase, and new solutions are generated in the acting phase. With regard to the process underpinning organizational learning, knowledge acquisition may be stimulated by planning and doing and the institutionalization and unlearning of knowledge may be enhanced by checking and acting.

The PDCA cycle may also promote workplace learning by stimulating experiential learning, as proposed by Kolb (1984). This model has been among the most influential in studies of management and has received a good deal of empirical support (Vince 1998; Kayes 2002; Mainemelis, Boyatzis and Kolb 2002; Meyer 2003). Kolb (1984) proposed a four-stage cyclical model: (1) concrete experience; (2) reflective observation; (3) abstract conceptualization; and (4) active experimentation. That is, immediate personal experiences are the bases for observation and reflection, and these are assimilated into abstract hypotheses or concepts. Then, these hypotheses or concepts guide learners to create new experiences. The PDCA cycle corresponds to Kolb's model in that concrete experiencing resembles doing, reflectively observing resembles checking, abstract conceptualizing resembles planning and actively experimenting resembles acting. These practices may enhance learning in the workplace by facilitating experiential learning.

Second, we found that the influence of OJT in promoting workplace learning depends on its style. The results indicate that empowerment has a positive impact on workplace learning, while direct supervision has a negative effect. As previous studies on team learning have indicated (Kirkman, Rosen, Tesluk and Gibson 2004; Gibson and Vermeulen 2003), empowerment can potentially reduce insecurity and defensiveness in the workplace, and can make teams more proactive in seeking continuous improvement, revising work processes and seeking innovative solutions to work problems.

On the other hand, direct supervision may prevent junior members from generating ideas and sharing them in the workplace, although it may promote individual learning. It is sometimes difficult to unlearn practices in workplaces with excellent superiors. Thus, OJT with direct supervision may hinder knowledge sharing and unlearning, but facilitate individual knowledge acquisition.

Finally, we found that reflective communication has a positive influence on workplace learning. This is consistent with previous studies on team learning, emphasizing the role of reflective communication in enhancing learning and performance of a team (Edmondson 1999; 
Gibson and Vermeulen 2003; van der Vegt and Bunderson 2005). Reflective communication may promote workplace learning because members need to transfer and combine insights through reflective communication to reach a common understanding of the experience (Gibson and Vermeulen 2003), and because it allows the critique of assumptions that are taken for granted, and encourages team members to be receptive to alternative ways of reasoning and behaving (Cunliffe 2002; Gray 2007).

The present research has implications for using managerial authority in the development of a learning-oriented workplace. First, quality management based on the PDCA cycle is an effective tool for facilitating workplace learning. By introducing PDCA practices, it may be possible to better create and share useful new knowledge and discard outdated knowledge in the workplace. Second, managers should distinguish between two types of OJT practices: empowerment and direct supervision. It is notable that empowerment can effectively facilitate learning among members, while direct supervision can sometimes hinder workplace learning. Finally, managers must promote reflective communication in the workplace, where members have a chance to express their opinions and criticize each other's work to improve performance perspectives. By combining PDCA practices and reflective communication, managers can enhance learning in the workplace.

The limitations of this study should be acknowledged. First, the sample in this study consisted of employees of Japanese firms. It is possible that national culture influenced the results. We need to test our research model further by conducting surveys in various industries and cultures. Second, we interpreted the role of the PDCA cycle in terms of problem solving and experiential learning. Empirical studies should be conducted to validate the effect of the PDCA cycle on these aspects of learning. Finally, the PDCA cycle has been examined primarily in the field of quality management, but the mechanisms by which the PDCA cycle facilitates learning have not yet been investigated. The role of the PDCA cycle in workplace learning needs to be examined in future research.

\section{References}

Barron, J.M., Berger, M.C., and Black, D.A. (1999), 'Do Workers Pay for On-the-Job Training?' Journal of Human Resources, 34, 2, 235-252.

Beattie, R. (2006), 'Line Managers and Workplace Learning: Learning From the Voluntary Sector,' Human Resource Development International, 9, 1, 99-119.

Benson, G.S. (2006), 'Employee Development, Commitment and Intention to Turnover: A Test of “Employability” Policies in Action,' Human Resource Management Journal, 16, 2, 173 192. 
Boud, D., and Garrick, J. (eds.) (1999), Understanding Learning at Work, London: Routledge.

Choo, A.S., Linderman, K.W., and Schroeder, R.G. (2007a), 'Method and Context Perspectives on Learning and Knowledge Creation in Quality Management,' Journal of Operations Management, 25, 918-931.

Choo, A.S., Linderman, K.W., and Schroeder, R.G. (2007b), 'Method and Psychological Effects on Learning Behaviors and Knowledge Creation in Quality Improvement Projects,' Management Science, 53, 3, 437-450.

Clarke, N. (2005), 'Workplace Learning Environment and Its Relationship With Learning Outcomes in Healthcare Organizations,' Human Resource Development International, 8, 2 , 185-205.

Clarke, N. (2006), 'Why HR Policies Fail to Support Workplace Learning: The Complexities of Policy Implementation in Healthcare,' International Journal of Human Resource Management, 17, 1, 190-206.

Cohen, S.G., and Ledford, G.E. (1994), 'The Effectiveness of Self-Managing Work Teams: A Quasi-Experiment,' Human Relations, 47, 643-676.

Conlon, T.J. (2004), 'A Review of Informal Learning Literature, Theory and Implications for Practice in Developing Global Professional Competence,' Journal of European Industrial Training, 28, 2-4, 283-295.

Crossan, M.M., Lane, H.W., and White, R.E. (1999), 'An Organizational Learning Framework: From Intuition to Institution,' Academy of Management Review, 24, 3, 522-537.

Cunliffe, A.L. (2002), 'Reflective Dialogical Practice in Management Learning,' Management Learning, 33, 1, 35-61.

Dahlgaard, K., and Kanji, G.K. (1995), 'Total Quality Management and Education,' Total Quality Management, 6, 5-6, 445-455.

Davies, J., and Easterby-Smith, M. (1984), 'Learning and Developing From Managerial Work Experiences,' Journal of Management Studies, 21, 2, 169-183.

Deming, W.E. (2000), The New Economics, for Industry, Government, Education (2nd ed.), Cambridge, MA: MIT Press.

Easterby-Smith, M., Crossan, M., and Nicolini, D. (2000), 'Organizational Learning: Debates Past, Present and Future,' Journal of Management Studies, 37, 6, 783-796.

Edmondson, A. (1999), 'Psychological Safety and Learning Behavior in Work Teams,' Administrative Science Quarterly, 44, 350-383.

Edmondson, A. (2002), 'The Local and Variegated Nature of Learning in Organizations: A Group-Level Perspective,' Organization Science, 13, 2, 128-146.

Edmondson, A.C., Bohmer, R.M., and Pisano, G.P. (2001), 'Disrupted Routines: Team Learning and New Technology Implementation in Hospitals,' Administrative Science 
Quarterly, 46, 685-716.

Fenwick, T. (2008), 'Understanding Relations of Individual-Collective Learning in Work:

A Review of Research,' Management Learning, 39, 3, 227-243.

Fox, S. (1997), 'From Management Education and Development to the Study of Management

Learning,' in Management Learning: Integrating Perspectives in Theory and Practice, eds.

J. Burgoyne and M. Reynolds, London: Sage, pp. 21-37.

Fuller, A., and Unwin, L. (2005), 'Older and Wiser? Workplace Learning From the Perspective of Experienced Employees,' International Journal of Lifelong Education, 24, 1, 21-39.

Garavan, T.N., Morley, M., Gunnigle, P., and McGuire, D. (2002), 'Human Resource

Development and Workplace Learning: Emerging Theoretical Perspectives and Organizational Practices,' Journal of European Industrial Training, 26, 2-4, 60-71.

Garvin, D.A. (1993), 'Building a Learning Organization,' Harvard Business Review, 71, July-August, 78-91.

George, J.M. (1990), 'Personality, Affect, and Behavior in Groups,' Journal of Applied Psychology, 75, 2, 107-116.

Gibson, C., and Vermeulen, F. (2003), 'A Healthy Divide: Subgroups as a Stimulus for Team Learning Behavior,' Administrative Science Quarterly, 48, 202-239.

Gray, D.E. (2007), 'Facilitating Management Learning Developing Critical Reflection Through Reflective Tools,' Management Learning, 38, 5, 495-517.

Gupta, A.K., and Govindarajan, V. (2000), 'Knowledge Flows Within Multinational Corporation,' Strategic Management Journal, 21, 473-496.

Hackman, J.R., and Wageman, R. (1995), 'Total Quality Management: Empirical, Conceptual, and Practical Issues,' Administrative Science Quarterly, 40, 2, 309-342.

Hodkinson, P. (2005), 'Reconceptualising the Relations Between College-Based and Workplace Learning,' Journal of Workplace Learning, 17, 8, 521-532.

Huber, G. (1991), 'Organizational Learning: The Contributing Processes and Literatures,' Organization Science, 2, 1, 88-115.

Institute of Personnel and Development (2000), Success Through Learning: The Argument for Strengthening Workplace Learning, London: IPD.

Jacobs, R.L., and Osman-Gani, A.A. (1999), 'Status, Impacts and Implementation Issues of Structured On-the-Job Training: A Study of Singapore-Based Companies,' Human Resource Development International, 2, 1, 17-24.

James, L.R., Demaree, R.G., and Wolfe, G. (1984), 'Estimating Within-Group Interrater Reliability With and Without Response Bias,' Journal of Applied Psychology, 69, 85-98. Jones, E.C., Parast, M.M., and Adams, S.G. (2010), 'A Framework for Effective Six Sigma Implementation,' Total Quality Management, 21, 4, 415-424. 
Kayes, D.C. (2002), 'Experiential Learning and Its Critics: Preserving the Role of Experience in Management Learning and Education,' Academy of Management Learning and Education, $1,2,137-149$.

Kirkman, B.L., Rosen, B., Tesluk, P.E., and Gibson, C.B. (2004), 'The Impact of Team Empowerment on Virtual Team Performance: The Moderating Role of Face-to-Face Interaction,' Academy of Management Journal, 47, 2, 175-192.

Kirkman, B.L., and Shapiro, D.L. (1997), 'The Impact of Cultural Values on Employee Resistance to Teams: Toward a Model of Globalized Self-Managing Work Team Effectiveness,' Academy of Management Review, 22, 730-745.

Kitching, J. (2007), 'Regulating Employment Relations Through Workplace Learning: A Study of Small Employers,' Human Resource Management Journal, 17, 1, 42-57.

Kolb, D.A. (1984), Experiential Learning: Experience as the Source of Learning and Development, Upper Saddle River, NJ: Prentice Hall.

Lopez, S.P., Peon, J.M.M., and Ordas, C.J.V. (2005), 'Human Resource Practices, Organizational Learning and Business Performance,' Human Resource Development International, 8, 147-164.

MacDuffie, J.P. (1997), 'The Road to "Root Cause": Shop-Floor Problem-Solving at Three Auto Assembly Plants,' Management Science, 43, 4, 479-502.

Mainemelis, C., Boyatzis, R.E., and Kolb, D.A. (2002), 'Learning Styles and Adaptive Flexibility: Testing Experiential Learning Theory,' Management Learning, 33, 5-33.

Marsick, V., and Watkins, K. (1990), Informal and Incidental Learning in the Workplace, New York: Routledge/Kegan Paul.

McDonnell, A., Gunnigle, P., and Lavelle, J. (2010), 'Learning Transfer in Multinational Companies: Explaining Inter-Organisation Variation,' Human Resource Management Journal, 20, 1, 23-43.

Meyer, J.P. (2003), 'Four Territories of Experience: A Developmental Action Inquiry Approach to Outdoor-Adventure Experiential Learning,' Academy of Management Learning and Education, 2, 4, 352-363.

Moon, J. (2004), A Handbook of Reflective and Experiential Learning, London/New York: RoutledgeFalmer.

Morrison, R.F., and Brantner, T.M. (1992), 'What Enhances or Inhibits Learning a New Job? A Basic Career Issue,' Journal of Applied Psychology, 77, 926-940.

Nevis, E.C., DiBella, A.J., and Gould, J.M. (1995), 'Understanding Organizations as Learning Systems,' Sloan Management Review, 36, winter, 73-85.

Nunnally, J.C. (1978), Psychometric Theory (2nd ed.), New York: McGraw-Hill.

O'Connor, B.N. (2004), 'The Workplace Learning Cycle: A Problem-Based Curriculum Model 
for the Preparation of Workplace Learning Professionals,' Journal of Workplace Learning, $16,6,341-349$.

Raelin, J.A. (2002), “'I Don't Have Time to Think!” Versus the Art of Reflective Practice,' Reflections, 4, 1, 66-79.

Rainbird, H., and Munro, A. (2003), 'Workplace Learning and the Employment Relationship in the Public Sector,' Human Resource Management Journal, 13, 2, 30-44.

Raper, P., Ashton, D., Felstead, A., and Storey, J. (1997), 'Toward a Learning Organisation? Explaining Current Trends in Training Practices in the UK,' International Journal of Training and Development, 1, 1, 9-21.

Rowden, R.W. (2002), 'The Relationship Between Workplace Learning and Job Satisfaction in U.S. Small to Midsize Businesses,' Human Resource Development Quarterly, 13, 4, 407425.

Sakakibara, K. (2004), 'Effects of On-The-Job Training Upon Self-Evaluated Job Performance Skills: On The Local Government Employees,' Japanese Association of Industrial/ Organizational Psychology Journal, 18, 1, 23-31.

Schön, D.A. (1983), The Reflective Practitioner: How Professionals Think in Action, New York: Basic Books.

Shewhart, W.A. (1931), Economic Control of Quality of Manufactured Product, New York: D. Van Nostrand.

Shewhart, W.A. (1939), Statistical Method From the Viewpoint of Quality Control, Washington, DC: The Graduate School, Department of Agriculture.

Slotte, V., Tynjala, P., and Hytonen, T. (2004), 'How Do HRD Practitioners Describe Learning at Work?' Human Resource Development International, 7, 4, 481-499.

Sorohan, E. (1993), 'We Do; Therefore We Learn,' Training and Development, 4, 10, 47-52.

Srivannaboon, S. (2009), 'Achieving Competitive Advantage Through the Use of Project Management Under the Plan-Do-Check-Act Concept,' Journal of General Management, 34, $3,1-20$.

Tang, J. (2008), 'The Implementation of Deming's System Model to Improve Security Management: A Case Study,' International Journal of Management, 25, 1, 54-68. Tippins, M.J., and Sohi, R.S. (2003), 'IT Competency and Firm Performance: Is Organizational Learning a Missing Link?' Strategic Management Journal, 24, 745-761.

van der Klink, M.R., and Streumer, J.N. (2002), 'Effectiveness of On-the-Job Training,' Journal of European Industrial Training, 26, 2-4, 196-199.

van der Sluis, L., Williams, R., and Hoeksema, L. (2002), 'Measuring the Quality of Managerial Learning on the Job,' International Journal of Human Resource Management, 13, 8, 12661278. 
van der Vegt, G.S., and Bunderson, J.S. (2005), 'Learning and Performance in Multidisciplinary Teams: The Importance of Collective Team Identification,' Academy of Management Journal, 48, 3, 532-547.

Vince, R. (1998), 'Behind and Beyond Kolb’s Learning Cycle,' Journal of Management Education, 22, 304-319.

Watkins, K., and Marsick, V. (1992), 'Toward a Theory of Informal and Incidental Learning in Organizations,' International Journal of Lifelong Education, 11, 4, 287-300.

Yukl, G. (2009), 'Leading Organizational Learning: Reflections on Theory and Research,' The Leadership Quarterly, 20, 49-53. 